\title{
真菌症を合併した上顎洞異物例
}

\author{
石川 正治・細川晃・萩原 明子* \\ 加藤 寿弥・三島 丈和・安藤 一郎*
}

\section{A Foreign Body (Root Canal Filling Material) in the Maxillary Sinus with Mycosis}

\author{
Masaharu Ishikawa, Akira Hosokawa, Toshiya Kato and Takekazu Mishima \\ (School of Medicine, Juntendo University)
}

Akiko Hagiwara and Ichiro Ando
(Juntendo Urayasu Hospital) tion.

We report a case of a foreign body in the right maxillary sinus in combination with a fungal infec-

The patient was a 35 year-old woman with nasal discharge and post nasal drips on the right side, in addition to right cheek pain and headache. She consulted a dentist, following the appearance of these symptoms, and headache. X-ray examination revealed a shadow in the right maxillary sinus, and the patient was admitted to our hospital, for further examination.

Past history included treatment of decay in the 4th and 5th upper right teeth.

She admitted to slight tenderness of the right cheek upon admission to hospital. The head Xray revealed a shadow on the side of right maxillary sinus and the material appeared to be a coilshaped foreign body which was not penetrated by the X-rays at the center of the right maxillary sinus. An examination of topography indicated similar changes, and also the root canal filling material was admitted. CT scan of the sinus showed soft tissue density in the right maxillary sinus and the presence of a high density region suggested the presence of metal at the center, surrounded by a ring of high density area.

Caldwell-Luc surgery was performed under general anesthesia. The maxillary sinus was filled with edematous mucous membrane and caseous material. A coiled string of hard material, approximately $1.5 \mathrm{~mm}$ in diameter, was extracted from inside the maxillary sinus. Pathological study revealed the material to be aspergillosis.

After surgery the patient's symptoms, including nasal discharge, post nasal drips and headache, disappeared.

Electron microscopic examination of the exposed sample, suggested it was composed of inorganic matter such as calcium and a chemical analysis indicated that calcium oxalate, and a sulfuric acid of barium were the main ingredients. Root canal filling material was thought to have left the root of the tooth clearing dental treatment, leading to subsequent inflammation in the maxillary sinus, and later to aspergillosis infection.

Key words : foreign body, maxillary sinus, mycosis 


\section{はじめに}

上顎洞異物に関する報告はこれまで耳鼻咽喉科，歯科， 口腔外科領域に和いて数多くなされている. 異物の侵入 経路としては，交通外傷にともなら顔面の外傷などのほ か，歯科治療による医原性のものも少なからず認められ， なかでも歯根，歯牙の報告が多い。今回我々は，鼻漏， 頭痛を主訴に来院し諸検査の結果，歯根管充填剤が上顎 洞内異物となり，上顎洞真菌症を合併した症例を経験し たのでここに報告する.

\section{症例}

患者 : 32歳, 女性.

初診: 平成 9 年 5 月 29 日.

主訴: 右側鼻漏, 後鼻漏, 右側煩部痛, 頭痛.

現病歴 : 平成 8 年暮孔頃より右鼻から膿性の鼻漏を認 めるよらになり，同時に，鼻閉，後鼻漏も認められた。 その後, 右側の頭痛も出現するよらになり, 平成 9 年 5 月近医雬科を受診し，レントゲン検査を施行され右側上 顎洞の陰影を指摘され同年 5 月29日当科初診.

既往歴，家族歴：特記すべき事項なし。屯た，ステロ イド剤，免疫抑制剤などの使用歴は無い、歯科的な治療 としては，平成 8 年に右上 $5,6,7$ 番の䠛歯の加療を行 って持り,さらに約 2 年程前に齲歯の加療を行っている
が詳細については不明である。

入院時所見 : 右側頓部の軽度の自発痛, 圧痛を認め, 鼻内所見では，粘膜の軽度の腫脹を認めたが，鼻漏の貯 留は認めず，また右上治療歯の検打痛も認めず，その他 耳鼻咽喉科領域には異常所見は認めなかった。また，血 液検査に持いても特に異常所見は認めなかった。

レントゲン所見（図 1)：単純レントゲン，ウォーター ス法では，右側上顎洞に片側性の陰影を認め，ほぼ中央 に，異物を疑わせるよらな螺旋状のレントゲン非透過性 物質を認めた。側面像に颃いても正面同様に非透過性物 質を認めた。副鼻腔断層検査(図 2 )では，単純レントゲ ソ検査と同様に右側上顎洞に片側性の陰影を認めた。陰 影はレントゲン非透過性物質を中心として認められ，上 顎洞上部，外側には，一部含気を認めた。また，側面像 に敃いては右上歯 6,7 番の歯根の治療を行われた像が 認められた。レントゲン単純，断層検査いずれも明らか な骨破壊像は認めなかった。

副鼻腔単純 CT 所見(㘠 3 ) : 右上顎洞を充満する濃淡 不均一の陰影像を認めた。陰影の中央にはレントゲン非 透過性物質を認め，さらにこの物質を囲をよらにリング 状に high density areaを認め, また左側と比較し, 上 顎洞の後壁，内側壁の骨肥厚を認めた。その他の副鼻腔 には，異常所見は認めず，CT上も明らかな骨の破壊像

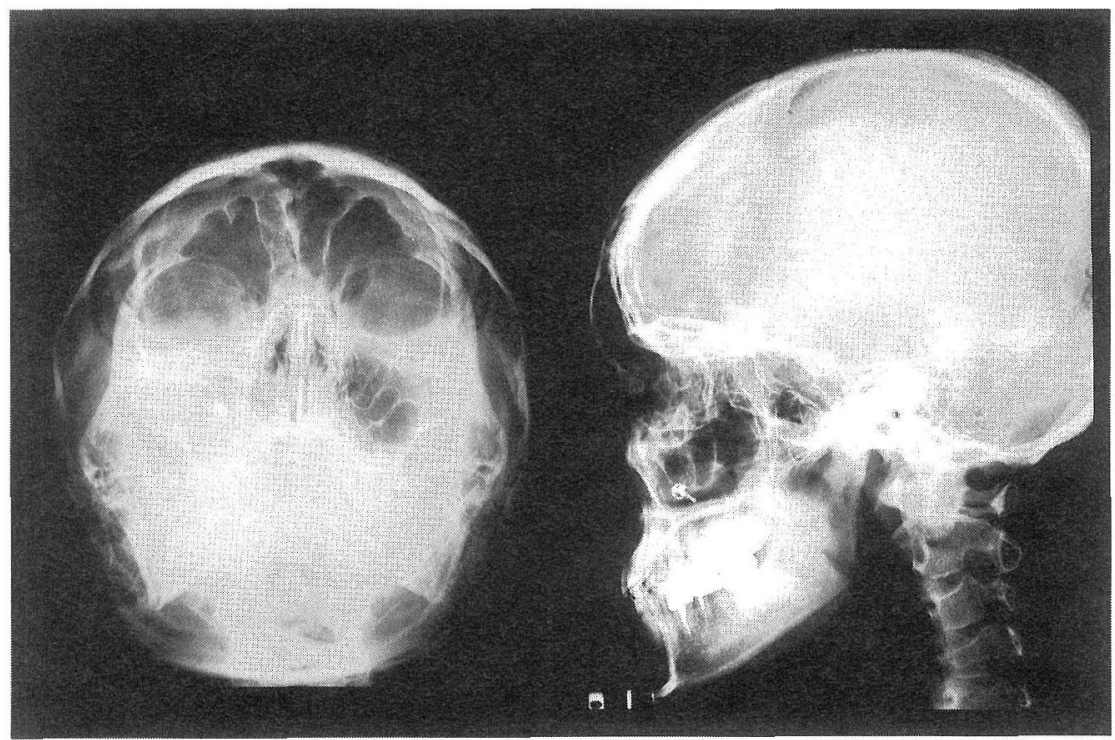

図 1 副鼻腔単純レントゲン写真 ウォータース法にて右側上顎洞に片側性の陰影を認め, 中央にレントゲン非 透過性の物質を認める。 


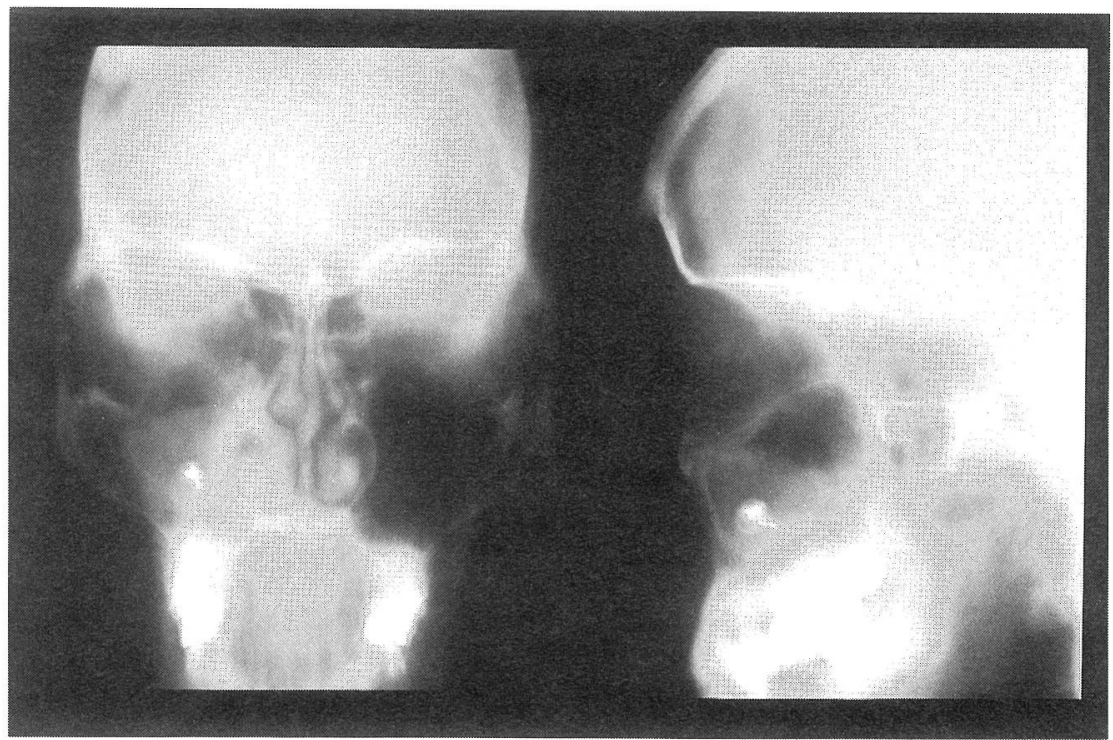

図 2 副鼻腔断層写真

右側上顎洞に片側性の陰影を認め, 中央にレントゲン非透過性物質を認める. 側面像にて, 歯根の加療された像を認める。明らかな骨破壊像は認められな W.

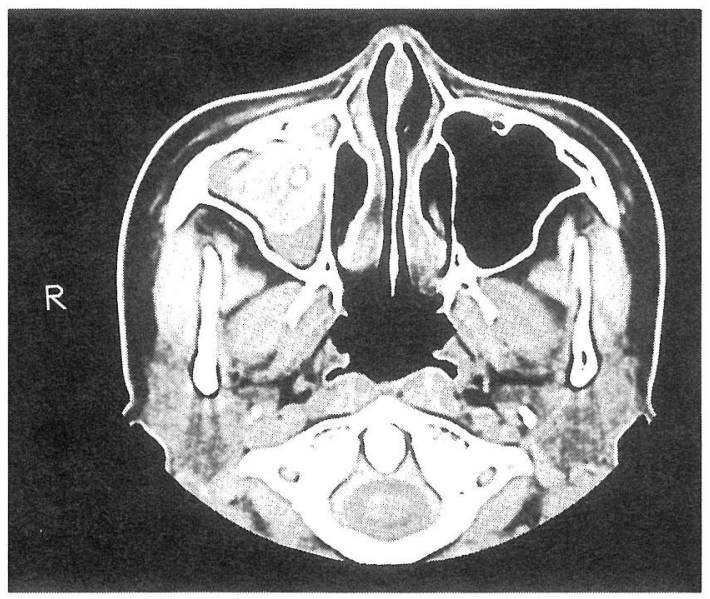

図 3 副鼻腔単純 CT 写真

右側上顎洞を充満する濃淡不均一の軟部組織像を認め, 中央にレントゲン非透過物質を認め, さらにその周辺に, high density area 認める。

は認めなかった。

手術所見：上記の様な検査結果より副鼻腔異物に伴う 片側性の副鼻空炎が最も疑われ, Caldwell-Luc 法に準 じて手術を施行した. 上領洞内は, 暗褐色の泥状物の貯 留を認め, また上顎洞粘膜の肥厚を認めた。摘出した泥
状物内には，レントゲン検査にて認められた螺旋状の異 物を認めた。 上顎洞内容物を充分除去し自然孔部を拡大 し手術を終了した.

摘出物所見(図 4)：肥厚した上顎洞粘膜内に泥状物の 付着を認めた. 病理学的検索では, 粘膜に関しては炎症 を伴う像を認め, 泥状物はアスペルギルスの菌塊という

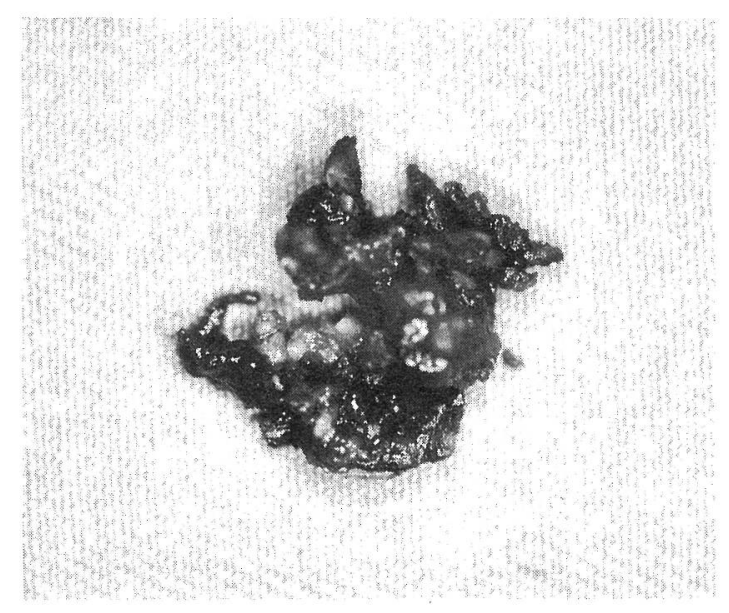

図 4 上顎洞内容物 肥厚した上顎洞粘膜内に泥状物の付着を認めた. 


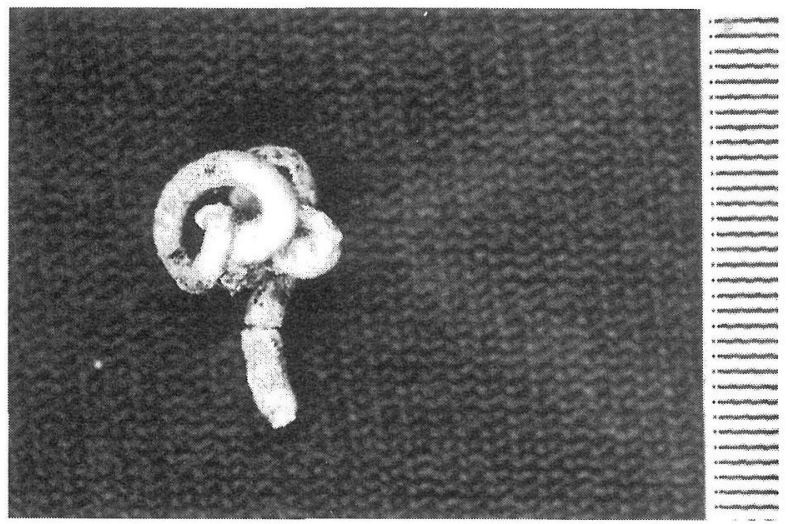

図 5 上顎洞内より摘出された異物 直径約 $1 \mathrm{~mm}$ の灰白色の硬い螺旋状物質を認めた。

結果であった。また，上顎洞より摘出された異物と思わ れる物質は直径約 $1 \mathrm{~mm}$ の扊白色の硬い螺旋状物質であ った(図 5 ). 摘出物質断面の走査電顕による検索では, 物質の断定はできないが，カルシウムの様な無機質の可 能性が高いとの結果であった（図 6 )。また，成分分析に 物いては, シュウ酸カルシウム, 硫酸バリウムを含さ物 質であり，水酸化カルシウム系の歯根管充填剤の可能性
が高いと考㝋られた。この結果とレントゲン像を合わせ， 齟歯の治療の際に使用された歯根管充填物が上顎洞内に 侵入したものと推定された.

術後経過は良好であり, 現在外来にて経過観察中であ る.

\section{考按}

上顎洞異物に関する報告は従来より多数認められる. 外傷性異物としては古くは空気銃弾やその他の銃弾が多 かった が，社会生活の変化に伴い交通外傷によるガラ ス片によるものが多数を占める様になった2). 一方医原 性異物としては，歯科治療に伴う歯牙，歯根の迷入が圧 倒的に多い2). 表 1 は中山ら ${ }^{2)}$ の報告による1963年から 82 年までの 20 年間の報告の内医原性異物に私共が渉猟し えた症例に本症例を加えたものを示すややはり解剖学的 位置関係より医原性異物上顎洞異物としては圧倒的に歯 牙，歯根異物が多く続いて歯科器材が多く認められる. 本症例のごとく根管充填剤の上顎洞迷入の症例はガータ パーチャポイントを含め 9 例の報告3) 7) が認められるの みで極めてまれなものと考光られ，な括かつ真菌症の合 併が示された報告は 3 例のみであった。
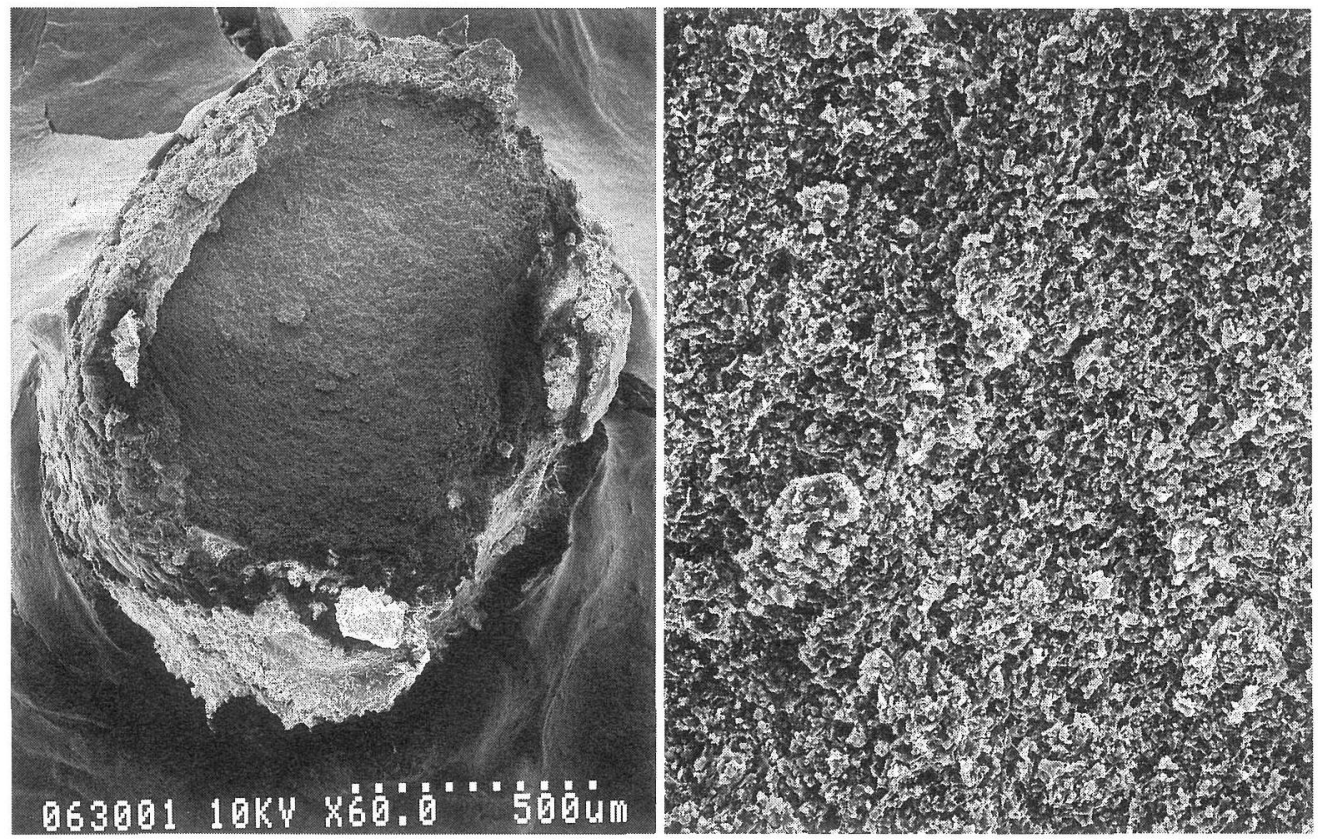

図 6 摘出物断面の走查電子顕微鏡像

電顕像のみからでは断定はできないが，カルシウムの上らな無機質の可能性が高いと考光られ た. 
表 1 医原性と考えられる上顎洞異物の報告例2)

\begin{tabular}{l}
\hline \hline 医療器材 \\
注射器, ガーゼ, ピンセット先端 \\
$\frac{\text { 歯科器材 }}{15 \text { 例 }}$ \\
歯管治療用ブローチ \\
造影剤 \\
根管充填剤 \\
歯科用レジン \\
ガータパーチャポイント \\
歯根ないし歯牙 $\quad 63$ 例 \\
\hline
\end{tabular}

1963年より1982年中山ら²)の報告に，1996年ま での医原性と考えられる症例を追加したものを 示す.

一方, 副鼻腔真菌症に関しても古くより多数の報告が なされている．罹患部位としては上顎洞が圧倒的に多く 片側性である事が汪とんどであり，時に骨破壊像を示す 症例にも遭遇することがあり上顎癌との鑑別が重要とな ることは耳鼻科医としては常識的事項である. 原因菌と しては asperugillus が最も多く次いで candida, mucor などが認められる ${ }^{8)}$. 診断としては, 鼻内分泌物や上顎 洞洗浄液の培養なども行われるが検出率は低くこれによ る術前診断は困難と考兄られる ${ }^{9)}$. 本症例に扣いても術 前の培養検査では陰性であり, 術後の上顎洞内容物の培 養検査に执いてでさえ $H$. Influenza を認めるのみであり， 最終的診断は病理検査を待つ必要があった。

画像学的診断では, 単純レントダン検査や断層撮影検 査, CT 検査, 最近では MRI 検査も行われるようにな ってきている. 副鼻腔真菌症のレントゲン検査の一般的 に見られる特徵として犬山ら ${ }^{10)}$ は(1)副鼻腔の片側性陰 影，(2) 上顎洞内壁と上壁の不鮮明，（3)篩骨洞境界壁の 不鮮明, (4) 中甲介の形態不鮮明, (5) 上顎洞内に fungus ball を思わせる陰影を認めることを挙げている. また CT 検査の特徵としては11) (1) 片側性に副鼻腔の一 部ないし全部に軟部組織濃度を示す病変を認める，(2) 上顎洞内特に自然孔付近に高吸収な部位の存在と患側洞 壁の硬化像を認める，（3）上顎洞内陰影の濃淡不均一と 一部石灰化を疑わせる高吸収域を示す，などが挙げられ る. 本症例に括いても単純レントゲン括よび副鼻腔断層 検査に扣いて上顎洞内に異物と考えられるレントゲン非 透過性物質を中心に軟部組織陰影を認めた。また断層撮 影側面像では歯根管の充填像が認められた。回顧的に考
えればこの時点で根管充填剤の上顎洞迷入が考えられた. また CT 検査では，上顎洞後壁の骨肥厚像が認められ， 上顎洞内には異物を中心にリング状に高吸収域な部位を 認めた.

先にも述べたように上顎洞異物の症例報告は多数認め られる. また, 副鼻腔真菌症の報告も多数認められる. しかし，副鼻腔特に上顎洞真菌症に执いて歯科的治療の 関連が疑われる症例は散見されるが，副鼻腔異物と根管 充填剂の関連が示されたものは，我々が渉猟しえた範囲 では本症例を含め 3 例のみであった。歯科治療により誘 発されたと考兄られる上顎洞真菌症につき中山ら5) は歯 科的要因が真菌症を引き起こしやすい炎症的環境を生ず るためではないかと述べているが，本症例に沶いても歯 科的治療により迷入した根管充填剤が上顎洞内に炎症を 生じ 2 次的に真菌感染が生じた可能性が強く疑われた.

\section{結語}

鼻漏，頭痛を主訴として来院した上顎洞異物症例を経 験した．手術的に上顎洞を開放したところ上顎洞内には 異物之泥状物を認め，異物は成分分析の結果水酸化力ル シウム系の歯根管充填剤と考兄られ，泥状物はアスペル ギルスの菌塊であった．上顎洞異物により炎症が生じ， 引き続き真菌感染が生じたものと考兄られ，文献的考察 を加え報告した。

本論文の要旨は, 平成 9 年11月, 第 6 回日本鼻科学会総会に て報告した.

稿を終えるに際し，御指導頂いた市川銀一郎教授に感謝いた します。

\section{参考文献}

1 ）佐藤武男, 中島章雄 : 上顎洞異物症例. 附, 本邦文献の統 計的観察. 耳鼻臨床 $56: 1 \sim 6,1963$.

2) 中山むつ久, 藤井一省, 斉藤成明 : 上䫇洞内歯科材料異物 の 1 症例ならびに最近の上顎洞異物に関する文献的考察. 耳喉 $55: 535 \sim 541,1983$.

3 ) 横川 正, 佐藤修久, 山野井弘充, 他：上顎洞内異物の 2 症例. 日大歯学 $57: 535 \sim 541,1983$.

4 ) 原田利夫, 斎藤 誠, 岡 政文, 他 : 上顎洞内迷入異物の 4 症例. 日口外誌 $30: 55 \sim 59,1984$.

5 ) 中山 均, 伊藤寿介, 小林富貴子, 他 : 真菌性上顎洞炎の 画像診断学的考察. 歯放 $32: 146 \sim 162,1992$.

6 ）南 吉昇, 亀井昌代, 笹生俊一, 他：上顎洞歯科材料異物 の 1 症例. 耳喉頭頸 $65: 155 \sim 159,1993$. 
7 ) 肥後芳樹, 福島淳夫, 金村成智, 他：上顎洞内異物の自然 排泄 2 症例. 日歯保誌 $37: 1270 \sim 1278,1994$ 。

8 ）前山裕之, 木村 洋, 戸島 均, 他: 当科に打梳副鼻腔 真菌症の検討.耳鼻臨床 補51：138～142, 1991.

9 ) 河合晃充, 折田洋造, 秋定 健, 他 : 副鼻腔真菌症の検討. 耳鼻臨床 補69：33４1, 1993.

10）犬山征夫, 小津雷助, 堀内正敏, 他 : 副鼻腔真菌症に関す る臨床的観察. 耳鼻臨床 $69: 325 \sim 335,1976$.
11）西川益利，西川恵子：上顎洞真菌症の CT 所見. 日耳鼻 $90: 319 \sim 323,1987$.

$$
\left.\begin{array}{l}
\text { 原稿受付 : 平成 } 10 \text { 年 } 3 \text { 月 } 6 \text { 日 } \\
\text { 原稿採択 : 平成 } 10 \text { 年 } 4 \text { 月 } 15 \text { 日 } \\
\text { 別刷請求先 : 石川正治 } \\
\text { † } 113-0033 \text { 東京都文京区本郷2-1-1 } \\
\text { 順天堂大学医学部耳鼻咽喉科学教室 }
\end{array}\right)
$$

